\title{
Determining Factors of Household Decision to Participate on Small Scale Irrigation Practices in Wolaita Zone, Ethiopia
}

\author{
Hailu Sodana Teka ${ }^{1} \quad$ Wubishet Genebo Godana ${ }^{2}$ \\ 1.Department of Economics, Wolaita Sodo University, PO Box 138, Wolaita Sodo, Ethiopia \\ 2.Department of Natural Resource Management, Wolaita Sodo University, Wolaita Sodo, Ethiopia
}

\begin{abstract}
Africa has been promoting small-scale irrigated agriculture as a means of ensuring food security as well as improving the standard of living of rural poor. The main aim of this study was to analyze the determining factors of household decision to participate on Small-Scale Irrigation Practices in Wolaita Zone, Ethiopia. The study employed both primary and secondary data sources. Primary data was collected from randomly selected 150 households through interview schedules. Data was analyzed using both descriptive and econometric methods of analysis. Descriptive result indicated that only $28.67 \%$ of households participate on small scale irrigation practices and it is still low as compared to large population size of Wolaita Zone. Collapsed canal banks, unstable embankments, leaking lining in elevated embankments, and cattle climbing in and out of the canal are identified as canal related problems whereas lack of appropriate water laws, absence of irrigation association bylaws, conflicts, and sense of ownership are also management problems. Binary logistic result also revealed that location of the household from upstream side of the river, higher household income, being young-aged household head, owning large number of livestock, better accessing market, being male headed household, and attending in higher education improve the household decision to participate on small scale irrigation practices. The authors strongly recommended government, non-governmental organizations, and other concerned stalk holders to give emphasis on intensifying the use of modern agricultural technologies, strengthening the existing irrigation potentials, providing periodic awareness training, and providing different water holding structures to non-users.
\end{abstract}

Keywords: smallholder farmers, small scale irrigation, participation, binary logistic model;

DOI: $10.7176 / \mathrm{JPID} / 57-02$

Publication date: December $31^{\text {st }} 2020$

\section{INTRODUCTION}

In Ethiopia agricultural production is mainly rain fed which is often erratic, unbalanced, and insufficient and becomes the main cause to low production and frequent food shortage. Irrigation has the potential to stabilize this variability in agricultural production and reduces its impact on people's livelihood (Abebawu et al, 2015). It has a multifaceted role in contributing towards food security, self-sufficiency, food production for the local market and exports (Chazovachii B., 2012). It has major positive impacts at household and village level and contributes significantly to Poverty Reduction Strategy objectives (Chiza C.K., 2005). There are four interrelated mechanisms by which irrigated agriculture improves household income and food security. To mention, it promotes greater use of yield enhancing farm inputs; increases farm production and productivity; plays greater role in additional employment creation; and protects poor households against risks of crop loss due to erratic, unreliable or insufficient rainfall (Haile T., 2008).

Although Ethiopia has 4.5 million ha of irrigable land, only 3.5\% of it has been covered through irrigation but large numbers of farmers are depending on rain-fed agriculture. Hence, the productivity level remained extremely low and susceptible to variability of agro- ecology (Tesfaw M., 2018). This fact is also applicable in Wolaita Zone as the problem of food deficit is prevailing at different time periods. Due to the erratic, unbalanced, unpredictable, and insufficient nature of rainfall, frequently agricultural production falls. In low altitude areas, delayed coming of rainy seasons, early withdrawal and its mal-distribution are common challenges that farmers frequently face. The report from Zonal Irrigation Development Office indicates that from the total potential of 2,392 hectare of land for irrigation in the Zone, only $28.8 \%$ is currently covered under irrigation by leaving majorities of farmers to lead subsistence agricultural production system than producing for market. As a result, for instance, in 2018, 27\% of the total populations of Wolaita Zone are the net beneficiaries of Productive Safety Net Program (PSNP) (WZIDO, 2018). Taking lessons from these existing challenges, government authorities at different levels are seriously trying to construct different irrigation schemes and water holding structures.

In this part, previously, almost no studies have been done in analyzing of the determining factors of household decision to participate on small scale irrigation practices in Wolaita Zone. Therefore, this study was motivated to analyze the determining factors that affect household decision to participate on small scale irrigation practices in Wolaita Zone, Ethiopia. The specific objectives of this study were: (1) to identify the existing problems on small scale irrigation schemes (2) to examine the existing management systems of small scale irrigation schemes (3) to explore the determining factors of household decision to participate on small scale irrigation practices in Wolaita Zone, Ethiopia. 


\section{MATERIALS AND METHODS}

\section{Description of the study area}

This research was conducted in three selected districts of Wolaita Zone, Ethiopia. Geographically, Wolaita Zone is located between $6^{\circ} 53^{\prime}-37^{\circ} 6^{\prime} 30^{\prime \prime}$ North Latitude and $37^{\circ} 46^{\prime}-37^{\circ} 58^{\prime} 40^{\prime \prime}$ East Longitude. It has an altitude ranging from 1501-2950 meters above sea level. It is located about $385 \mathrm{KMs}$ south west of Addis Ababa. It boarders with Gamo Gofa zone from South, Dawuro Zone from West, Sidama zone from East, Kambata and Tambaro, and Hadiya Zones from Northern East. The Zone comprises a total rural population of 2,473,190 and a total of 357,904 HHs. Agriculture is the main stay for more than 90 percent of the total population and mixed farming system involving crop production and livestock rearing is the main stay of rural households in the Zone. The total potential of land for irrigation in the zone is about 2392 hectare and currently 689 hectare $(28.8 \%)$ of land is covered under irrigation (WZIDO, 2018).

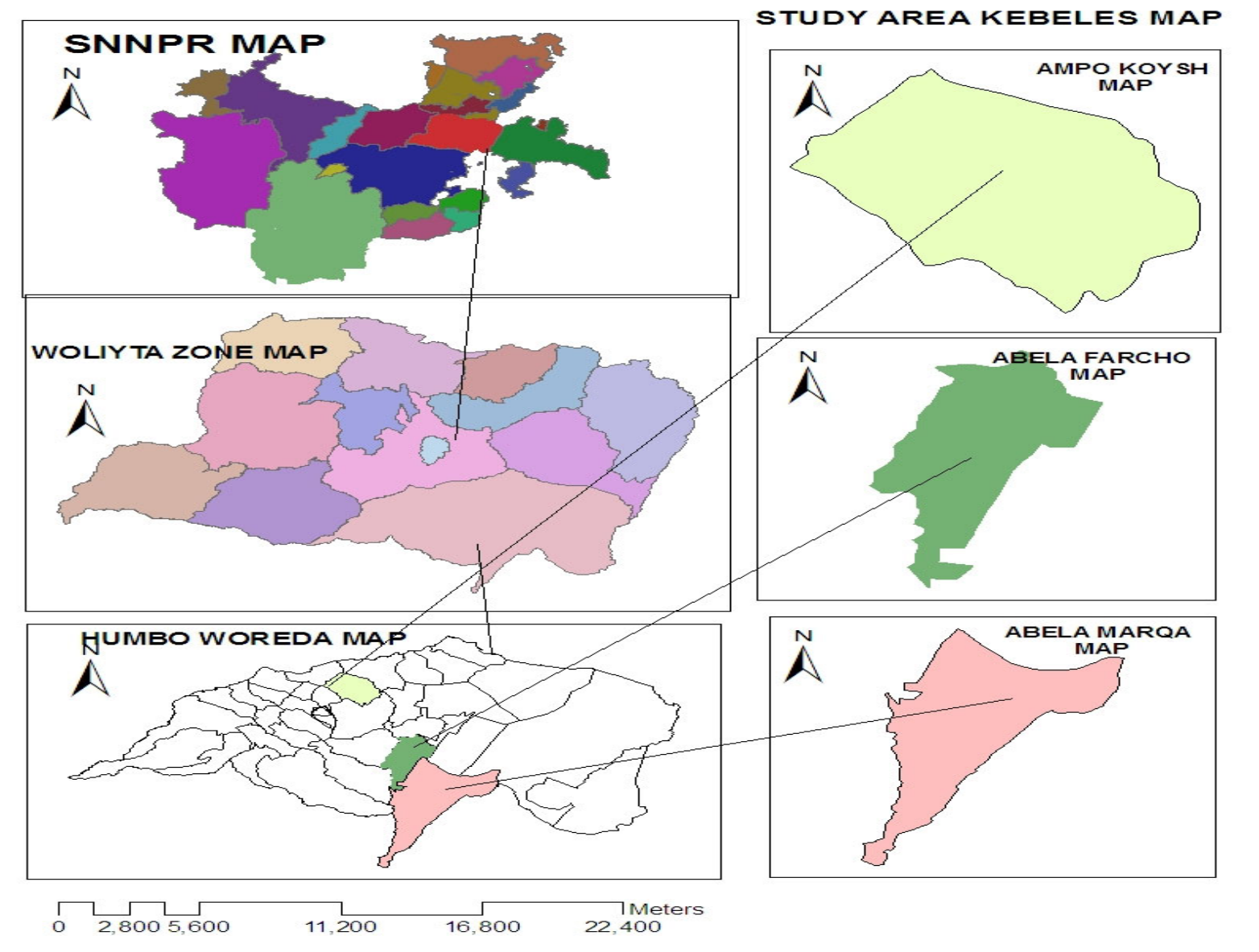

Figure 1: Study area map

There are three main rivers (namely: Bilate river, Hamesa river and Lintala river) that people use to irrigate their crop and are crossing the study area. Nine irrigation schemes are constructed at different corners of these three main rivers and among them, six are small scale irrigation schemes and three are medium scale irrigation schemes. On Bilate river, four irrigation schemes (namely: Abaya Bisare, Abaya Gurucho, Abaya Chokare and Abaya Bilate) were constructed to irrigate lands for four kebeles in Abela Abaya and Hobicha Abaya districts. On Hamesa river, four irrigation schemes (namely: Ela-Ampo, Bossa-Wanche, Abela Faracho and Abela-Lasho) were also constructed to irrigate lands of Humbo district and Abela Abaya district. On Lintala river, one irrigation scheme (namely: Sere Tawurata) was constructed to irrigate land from one kebele of Humbo district in Wolaita Zone. However, this study mainly focused on the three of small scale irrigation schemes (namely: Ela-Ampo, Abela-Lasho and Abaya Bissare) from the three selected districts in the Zone. 
Table 1: Main irrigation schemes in Humbo District

\begin{tabular}{|l|l|l|l|l|l|l|}
\hline No & $\begin{array}{l}\text { Name of } \\
\text { schemes }\end{array}$ & $\begin{array}{l}\text { Types of } \\
\text { schemes }\end{array}$ & $\begin{array}{l}\text { The district it } \\
\text { found }\end{array}$ & $\begin{array}{l}\text { Maximum } \\
\text { potential }\end{array}$ & $\begin{array}{l}\text { Covered area } \\
\text { in ha }\end{array}$ & $\begin{array}{l}\text { Direct/ indirect/ } \\
\text { beneficiary HH }\end{array}$ \\
\hline 1 & Abaya Bilate & Traditional & Hob. Abaya & 410 & 240 & 278 \\
\hline 2 & Abaya Gurucho & Traditional & Abe. Abaya & 310 & 220 & 610 \\
\hline 3 & Abaya Bisare & Modern & Hob. Abaya & 402 & 200 & 221 \\
\hline 4 & Abaya Chokare & Traditional & Abe. Abaya & 301 & 160 & 270 \\
\hline 5 & Bossa Wanche & Modern & Humbo & 189 & 100 & 53 \\
\hline 6 & Ela Ampo & Modern & Humbo & 245 & 108 & 213 \\
\hline 7 & Abela Faracho & Modern & Abe. Abaya & 170 & 80 & 68 \\
\hline 8 & Abela Lasho & Modern & Abe. Abaya & 230 & 110 & 135 \\
\hline 9 & Lintala & Modern & Humbo & 135 & 70 & 24 \\
\hline & Total potential & & & $\mathbf{2 3 9 2}$ & $\mathbf{1 2 8 8}$ & $\mathbf{2 1 0 4}$ \\
\hline
\end{tabular}

Research design: The study employed mixed research design meaning both qualitative and quantitative research approaches were used. Mixed methods provide the opportunity for presenting a greater diversity of divergent views. Using a combination of quantitative and qualitative methods of analysis helps the researchers to get more reliable data (John Creswell, 2014).

\section{Data sources and Method of data collection}

The data for this study was obtained from both primary and secondary sources. The primary data was collected through interview schedule from 150 randomly selected HHs around three small scale irrigation schemes such as Ela-Ampo, Abela-Lasho, and Abaya Bissare irrigation schemes. The relevant secondary data were also acquired from published and unpublished documents of Zonal and selected districts' Agricultural and Rural Development Office and Irrigation Development Office.

\section{Sample Size and Sampling Technique}

Multi-stage (i.e. combination of purposive, stratified, and simple random sampling) sampling technique was employed to obtain necessary data from both irrigation users and non-user households. In the first stage, out of six potential modern small-scale irrigation schemes, three schemes (namely: Ela-Ampo, Abela-Lasho, and Abaya Bissare) were purposively selected. In the second stage, total number of $\mathrm{HH}$ heads of the study area was stratified into two as irrigation users and non-users based on their list obtained from water use committees. Then sample respondents were randomly selected from the residences around each selected irrigation scheme using simple random sampling technique. To determine total sample size, a simplified formula provided by Yemane, (1967) was used at $7 \%$ precision and $95 \%$ confidence level. $\mathbf{n}=\mathrm{N} / 1+$

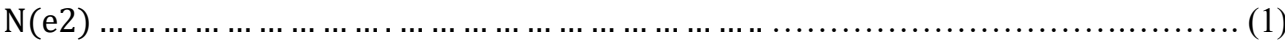

Where; $\mathrm{n}=$ the total sample size of study from 3 sample irrigation schemes; $\mathrm{N}=$ the total HH size of three sample irrigation schemes (569); and $\mathrm{e}=$ is acceptable level of sampling error (7\%). Based on the number of the total HHs in the sampling frame, the formula equated and reached a minimum of 150 respondents from users and non-users.

\section{Model Specification}

Since the response variable "household decision to participate on small scale irrigation practices" is dichotomous that takes a value 1 if the households are irrigation users and 0 otherwise, binary logistic regression model was employed in analyzing the determining factors of household decision to participate on small-scale irrigation practices. This model satisfies the condition required by dichotomous nature of response variables. Thus, the response variable in this case, household decision to participate on small scale irrigation practice, is dummy in nature which takes 0 or 1 depending on whether the $\mathrm{HH}$ participate on small scale irrigation or not. As Hosmer and Lemeshow.(2008) pointed out, binary logistic model has an advantages over other models is that it is an extremely flexible and easily usable model, results in a meaningful interpretation, represents a close approximation to the cumulative normal distribution, and easy to work with.

The standard Binary Logistic model with several determining variables is commonly written as: - $\mathrm{Pi} /(1-\mathrm{Pi})=$ $\left(1+\mathrm{e}^{\mathrm{Zi}}\right) /\left(1+\mathrm{e}^{-\mathrm{Zi}}\right)=\mathrm{e}^{\mathrm{Zi}}$

Where: $\mathrm{Pi}$ is the probability that a $\mathrm{HH}$ doesn't participate on irrigation practice; 1-Pi is the probability that a $\mathrm{HH}$ participate on irrigation practice; e is the base of natural logarithm. Now $\mathrm{Pi} /(1-\mathrm{Pi})$ is simply the odds in favor of participating on small scale irrigation practice: - the ratio of the probability that HH doesn't participate on SSI practice to the probability that a $\mathrm{HH}$ participate on small scale irrigation practice. The general form of logistic equation of the included explanatory variables with their expected signs was presented like this:

HDPSSI $=\alpha+\beta_{1}$ Locriv $+\beta_{2}$ HHI $+\beta_{3}$ Tlsha $+\beta_{4}$ Educ $+\beta_{5}$ Hhsize $+\beta_{6}$ livtnubr $+\beta_{7}$ Amkt $+\beta_{8}$ Sex $+\beta_{9}$ Age + $\beta_{10} \mathrm{Crdt}+\beta_{11}$ Tranig $+\beta_{12}$ ExnDA 
Where; $\alpha$ is intercept of the model; $\beta_{1} \ldots \beta_{i}$ are coefficients of the determining variables; HDPSSI denote the probability of household decision to participate on SSI practice and takes the value 1 or 0 .

\section{Definition of the study variables}

Household decision to participate on SSI practices (HDPASSI): the variable HH decision to participate on SSI practice was used in the model as response variable and treated as dummy that takes 0 if the household is nonirrigation user and 1 if the $\mathrm{HH}$ is irrigation user.

Determining variables: in this study, different variables were introduced in to the model as determining factors of HH decision to participate on SSI practices. They were treated according to their nature i.e. location of $\mathrm{HH}$ from river stream (Locriv) treated as discrete variable $[0$ if the $\mathrm{HH}$ located at downstream, 1 if at middle stream, and 2 if at upstream side], monthly $\mathrm{HH}$ income (HHI) as categorical variable $[0=<500$ birr, $1=500-1000,2=1001$ $30003=3001-5000,4=>5000]$; landholding size (Tlsha) as categorical $[0=<1$ ha, $1=1-1.5,2=>1.5 \mathrm{ha}]$; education level of household head (Educ) as discrete $[0=$ illiterate, $1=$ primary class complete, $2=$ secondary class complete, $3=$ higher class complete]; HH size (Hhsize) as categorical $[0=1-3$ family members, $1=4-8,2=>8$ members]; number of livestock (livtnubr) as categorical [0 =1- 3 livestock, $1=4-8,2=>8$ livestock]; access to market (Amkt) as dummy [0 if no access to market and 1 if better access]; sex of HH head (Sex) as dummy [0 female headed and 1 male headed]; age of $\mathrm{HH}$ head (Age) as categorical [ $3=25-34$ years, $2=35-49,1=50-60$, $0=>60$ years]; credit use (Crdt) as dummy [0 if not credit user, 1 if credit user]; attending on training (Tranig) as dummy [0 if the $\mathrm{HH}$ doesn't take any training, 1 if take training]; and access to timely extension contact (Extenda) as dummy [0 if no access, 1 if better access to timely extension contact].

\section{RESULTS AND DISCUSSION \\ DESCRIPTIVE ANALYSIS}

Demographic factors: most of rural households $(81.33 \%)$ are male headed and $18.67 \%$ are female headed (Figure 1). To see this on user-non-user basis, $90.67 \%$ of irrigation users are male headed and $9.33 \%$ of them are female headed whereas $73.33 \%$ of non-irrigation users are male headed and $26.67 \%$ of them are female headed (Table 3 ). This tells that males are actively participating in small scale irrigation practices than women. On the other side, $19.33 \%$ of the respondents are old-aged ( $>60$ years), $27.33 \%$ of them are at age category of 50 and 60 years, $47.33 \%$ of them are at age category of 36 and 49 years, and $6 \%$ are at age category of between 25 and 35 years (Figure 2). To see this on user-non-user basis, $2.67 \%$ of irrigation user $\mathrm{HH}$ heads are old-aged ( $>60$ years), $12 \%$ of them are between 50 and 60 years, $74.67 \%$ of them are between 35 and 49 years, and $10.66 \%$ are between 25 and 34 years whereas $34.67 \%$ of non-users are old-aged, $41.33 \%$ of them are between 50 and 60 years, $21.33 \%$ are between 35 and 49 years, and $2.67 \%$ are between 25 and 34 years (Table 3 ).

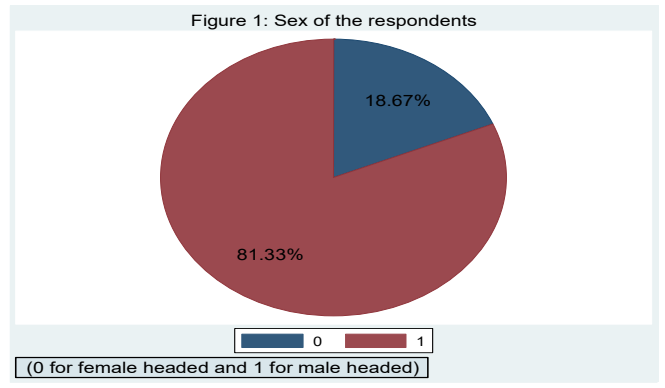

Source: Field Survey, Feb, 2020

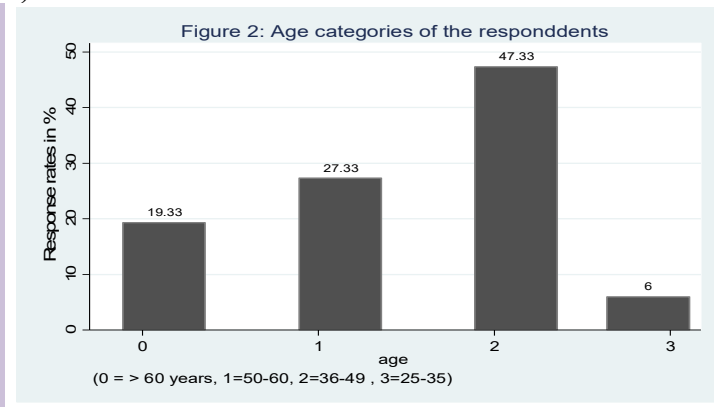

Source: Field Survey, Feb. 2020

\section{Socio-economic characteristics of respondents}

Education level of $\mathrm{HH}$ head was taken as one of the determining variable of $\mathrm{HH}$ decision to participate on SSI practices as it affects farmer's ability to acquire process and use information relevant to agricultural technologies. Accordingly, $32 \%$ of the $\mathrm{HH}$ heads were illiterate, $35.33 \%$ were primary class complete, $22 \%$ were secondary class complete, and only $10.67 \%$ were higher classes complete (Figure 3 ). To see this frequency distribution on user-non-user basis, $14.67 \%$ of irrigation users were illiterate, $52 \%$ were primary class complete, $20 \%$ were secondary class complete, and $13.33 \%$ were higher class complete whereas $49.33 \%$ of non-irrigation users were illiterate, $48 \%$ were primary class complete, $2.67 \%$ were secondary class complete, and none of them attended in higher classes (Table 3 ). 


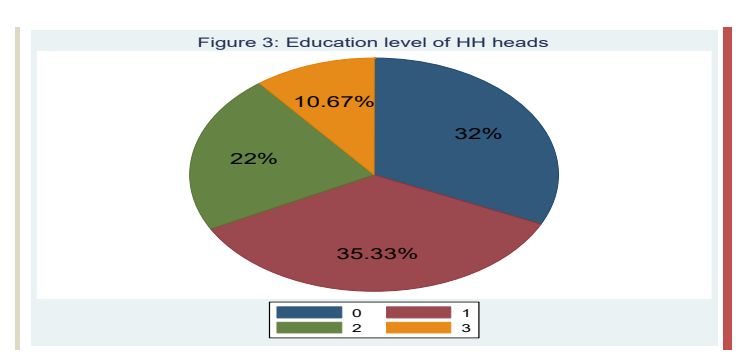

Source: Field Survey, Feb, 2020

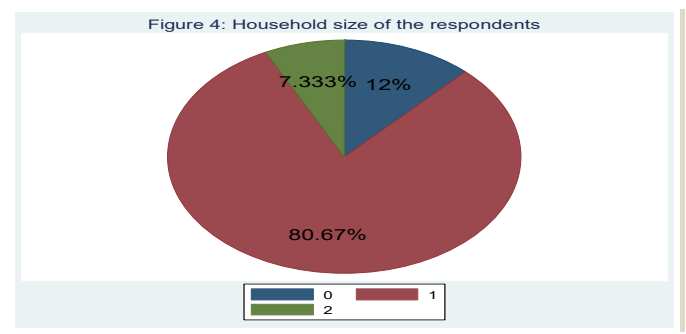

Source: Field Survey, Feb, 2020

Household size was also taken as another important variable to determine HH decision to participate on SSI practices. Accordingly, $12 \%$ of households have smaller family size ( $1-3$ members), $80.67 \%$ have medium family size (4-8 members) and $7.33 \%$ have larger family size ( $>8$ members) (Figure 4$)$. To see this on user-non-user basis, $14.67 \%$ of irrigation users have smaller family size, $77.33 \%$ have medium family size, and $8 \%$ have larger family size whereas $41.33 \%$ of non-irrigation users have smaller family size, $53.33 \%$ have medium family size, and $5.34 \%$ have larger family size (Table 3).

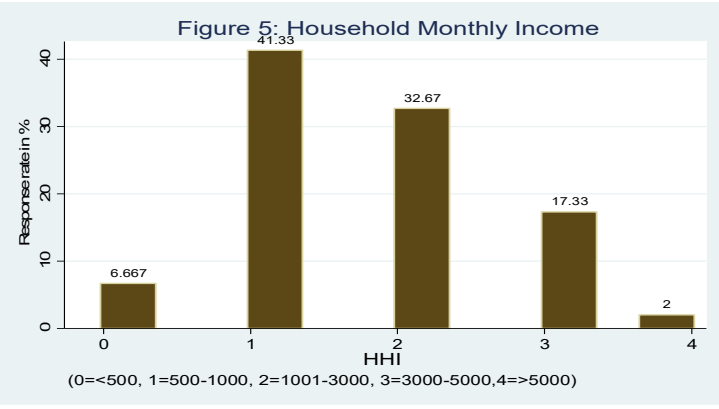

Source: Field Survey, June, 2020

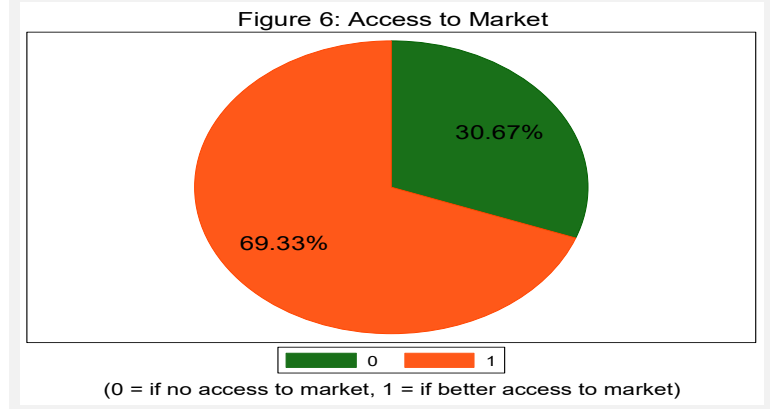

Source: Field Survey, June, 2020

Another important variable that was considered to determine HH decision to participate on SSI practice is "monthly household income". As the result shown, $6.67 \%$ of the households have $<500$ birr of monthly income, $41.33 \%$ have between 500 and 1000 birr, 32.87\% have between 1001 and 3000 birr, $17.33 \%$ have 3001-5000 birr, and only $2 \%$ have $>5000$ birr monthly income (Figure 5). To see this on user-non-user basis, none of irrigation users have monthly income of $<500 \mathrm{birr}, 8 \%$ of them earn between 500 and $1000 \mathrm{birr}, 26.67 \%$ between 1001 and 3000 birr, $28 \%$ between 3001 and 5000 birr, and $37.33 \%$ of them earn beyond 5000 birr whereas $18.67 \%$ of nonusers earn $<500$ birr, $38.67 \%$ between 500 and 1000 birr, $21.33 \%$ between 1001 and 3000 birr, $16 \%$ between 3001 and 5000 birr, and $5.33 \%$ of them earn beyond 5000 birr (Table 3).

Household decision to participate on SSI practices was also determined by access to market. Accordingly, $69.33 \%$ of households have better access to market and $30.67 \%$ have no access to it (Figure 6). To see this figure on user-non-user basis, only $12 \%$ of irrigation users have no access to market and $88 \%$ of them have better access to it whereas $65.33 \%$ of non-users have no access to market and $34.67 \%$ have access to market (Table 3 ).

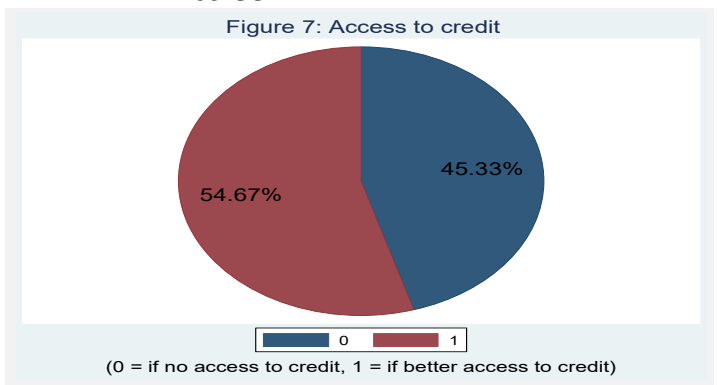

Source: Field Survey, June, 2020

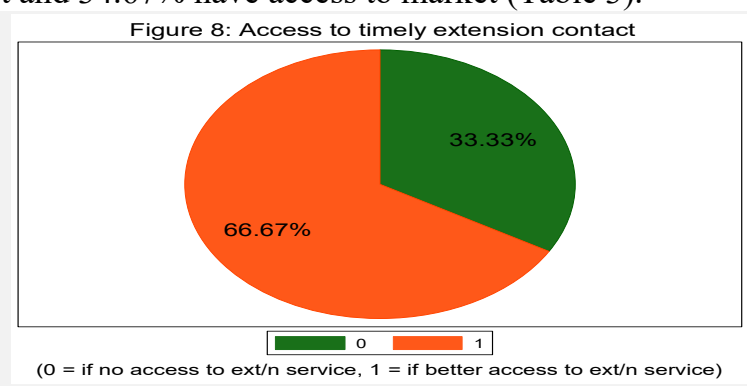

Source: Field Survey, June, 2020

The variable "access to credit use" is also included as determinant factor to change the HH decision to participate on SSI practices. Accordingly, 54.67\% of respondents have better access to credit use and $45.33 \%$ have no access to it (Figure 7). To see this on user-non-user basis, 30.67\% of irrigation users have no access to credit service and $69.33 \%$ of them have better access to credit whereas $60 \%$ of non-irrigation users have no access to credit and $40 \%$ of them better accessing it (Table 3 ).

Access to timely extension contact is also another variable to determine HH decision to participate on SSI practices. Accordingly, $66.67 \%$ of the respondents have no access to timely extension contact and $33.33 \%$ of them have better access to it (Figure 8). To see this figure on user-non-user basis, $70.67 \%$ of irrigation users are better accessing timely extension contact and $29.33 \%$ of them have no access to it whereas $50.67 \%$ of non-users are better accessing timely extension contact and $49.33 \%$ of them have no access to it (Table 3 ). 
Accessing adequate land size for crop production is of crucial in encouraging HH participation on SSI practices. To this end, $30 \%$ of HHs own on average $<1$ hectare, $61.33 \%$ from 1 up to 1.5 hectare, and $8.67 \%$ of them own $>1.5$ hectare of total land (Table 2). To see this on user-non-user basis, $4 \%$ of irrigation users own $<1$ hectare, $66.67 \% 1$ up to 1.5 hectare, and $29.33 \%$ of them own $>1.5$ hectare whereas $26.67 \%$ of non-irrigation users own $<1$ hectare, $50.67 \% 1$ up to 1.5 hectare, and $22.66 \%$ of them own $>1.5$ hectare of total land (Table 3 ).

Table 2: Institutional factors

\begin{tabular}{|lllll|}
\hline Variables & & Categories and its code & Freq. & Percentage \\
\hline Landholding size & Categorical & $0=<1$ ha total land size & 45 & 30 \\
& & $1=1-1.5$ ha total land size & 92 & 61.33 \\
& & $2=>1.5$ ha total land size & 13 & 8.67 \\
Livestock ownership & Categorical & $0=1-3$ livestock number & 39 & 26 \\
& & $1=4-8$ livestock number & 94 & 62.67 \\
& & $2=>8$ livestock number & 17 & 11.33 \\
Training & \multirow{2}{*}{ Dummy } & $0=$ if not trained & 107 & 71.33 \\
Location of HHs from & Discrete & $1=$ if trained & 43 & 28.67 \\
river side & & $1=$ at downstream & 51 & 34 \\
& & $2=$ at upstream & 49 & 32.67 \\
\hline
\end{tabular}

Number of livestock owned is also another variable to determine HH decision to participate on SSI practices. Accordingly, $26 \%$ of HHs own small number of livestock ( 1 up to 3), 62.67\% own 4 up to 8 , and $11.33 \%$ own large number of livestock ( $>8$ livestock) (Table 2). To see this figure on user-non-user basis, $6.67 \%$ of irrigation users own smaller livestock number, $77.33 \%$ own 4 up to 8 livestock, and $16 \%$ own $>8$ livestock whereas $46.67 \%$ of non-irrigation users own a smaller livestock size, $48 \%$ own 4 up to 8 livestock, and 5.33\% of them own larger livestock number.

Training is also included as a study variable to determine HH decision to participate on SSI practices. As a result, only $28.67 \%$ of the total respondents have got training on their farming activities, land use, and irrigation water utilization whereas $71.33 \%$ didn't get training (Table 2). To see this on user-non-user basis, $46.67 \%$ of irrigation users have got training and $53.33 \%$ didn't get training whereas $16 \%$ of non-users have got training and $84 \%$ didn't get it (Table 3 ).

Lastly, we have stratified irrigation users in to upstream, middle and downstream beneficiaries based on their location with the basic assumption that there is inequality in water distribution. Accordingly, $34 \%$ of the total households are located at the downstream river side, $32.67 \%$ at the middle stream, and $33.33 \%$ of them located at the upstream river side (Table 2). To see this figure on user-non-user basis, $10.67 \%$ of the irrigation users located at downstream, $36 \%$ at middle stream, and $53.33 \%$ of them at upstream river side whereas $54.67 \%$ of non-users located at downstream river side, $30.67 \%$ at middle stream river side, and $14.66 \%$ of them located at upstream river side (Table 3 ). 
Table 3: Socio-economic characteristics of HHs on User-Non-User basis

\begin{tabular}{|c|c|c|c|c|c|}
\hline \multirow[t]{2}{*}{ Variable } & \multirow[t]{2}{*}{ Variable code } & \multicolumn{2}{|c|}{ Users } & \multicolumn{2}{|c|}{ Non users } \\
\hline & & Freq. & $\%$ & Freq. & $\%$ \\
\hline \multirow[t]{5}{*}{$\mathrm{HHI}$} & $0=<500 \mathrm{HHI}$ monthly income & 0 & 0 & 14 & 18.67 \\
\hline & $1=500-1000$ monthly income & 6 & 8 & 29 & 38.67 \\
\hline & $2=1001-3000$ monthly income & 20 & 26.67 & 16 & 21.33 \\
\hline & $3=3001-5000$ monthly income & 21 & 28 & 12 & 16 \\
\hline & $4=>5000$ monthly income & 28 & 37.33 & 4 & 5.33 \\
\hline \multirow[t]{3}{*}{ TLS Ha } & $0=<1$ ha total land size of farmer & 3 & 4 & 20 & 26.67 \\
\hline & $1=1-1.5$ ha total land size of farmer & 50 & 66.67 & 38 & 50.67 \\
\hline & $2=>1.5$ ha total land size of farmer & 22 & 29.33 & 17 & 22.66 \\
\hline \multirow[t]{4}{*}{ Educ } & $0=$ illiterate & 11 & 14.67 & 37 & 49.33 \\
\hline & $1=$ primary & 39 & 52 & 36 & 48 \\
\hline & $2=$ secondary & 15 & 20 & 2 & 2.67 \\
\hline & $3=$ higher class complete & 10 & 13.33 & 0 & 0 \\
\hline \multirow[t]{3}{*}{ Hhsize } & $0=1-3$ family member & 11 & 14.67 & 31 & 41.33 \\
\hline & $1=4-7$ family member & 58 & 77.33 & 40 & 53.33 \\
\hline & $2=>8$ family member & 6 & 8 & 4 & 5.34 \\
\hline \multirow[t]{3}{*}{ Livtnubr } & $0=1-3$ livestock number & 5 & 6.67 & 35 & 46.67 \\
\hline & $1=4-8$ livestock number & 58 & 77.33 & 36 & 48 \\
\hline & $2=>8$ livestock number & 12 & 16 & 4 & 5.33 \\
\hline \multirow[t]{2}{*}{ Amkt } & $0=$ if no access & 9 & 12 & 49 & 65.33 \\
\hline & $1=$ if access & 66 & 88 & 26 & 34.67 \\
\hline \multirow[t]{2}{*}{ Sex } & $0=$ female & 7 & 9.33 & 20 & 26.67 \\
\hline & $1=$ for male & 69 & 90.67 & 55 & 73.33 \\
\hline \multirow[t]{4}{*}{ Age } & $0=>60$ age household head & 2 & 2.67 & 26 & 34.67 \\
\hline & $1=50-60$ age household head & 9 & 12 & 31 & 41.33 \\
\hline & $2=35-49$ age household head & 56 & 74.67 & 16 & 21.33 \\
\hline & $3=25-34$ age household head & 8 & 10.66 & 2 & 2.67 \\
\hline \multirow[t]{2}{*}{ Crdt } & $0=$ if not use & 23 & 30.67 & 45 & 60 \\
\hline & $1=$ if use & 52 & 69.33 & 30 & 40 \\
\hline \multirow[t]{2}{*}{ Tranig } & $0=$ if not train & 40 & 53.33 & 63 & 84 \\
\hline & $1=$ if train & 35 & 46.67 & 12 & 16 \\
\hline \multirow[t]{2}{*}{ ExtenDA } & $0=$ if not get support & 22 & 29.33 & 37 & 49.33 \\
\hline & $1=$ if get support & 53 & 70.67 & 38 & 50.67 \\
\hline \multirow[t]{3}{*}{ Locriv } & $0=$ to downstream & 8 & 10.67 & 41 & 54.67 \\
\hline & $1=$ to middle stream & 27 & 36 & 23 & 30.67 \\
\hline & $2=$ to head stream & 40 & 53.33 & 11 & 14.66 \\
\hline
\end{tabular}

Source: own computation from survey data, 2020

\section{Problems Identified in relation to SSI Practices}

Canal related problems: the management of collection, storage and conveyance system in project is a critical factor in the performance analysis of irrigation system at the $\mathrm{HH}$ level as much of losses and inadequacies occur at this level. To this end, poor canal conditions like collapsed canal banks; unstable embankments; leaking lining in elevated embankments; crabs and other animals dig holes in the embankment; and cattle climbing in and out of the canal were observed during the survey period. These all problems led to canal deterioration, reduced flow and frequent disturbance of irrigation supply (Figure 9). 
Figure 9: Canal collapse and deterioration in Abela-Lasho \& Ela-Ampo Irrigation Schemes

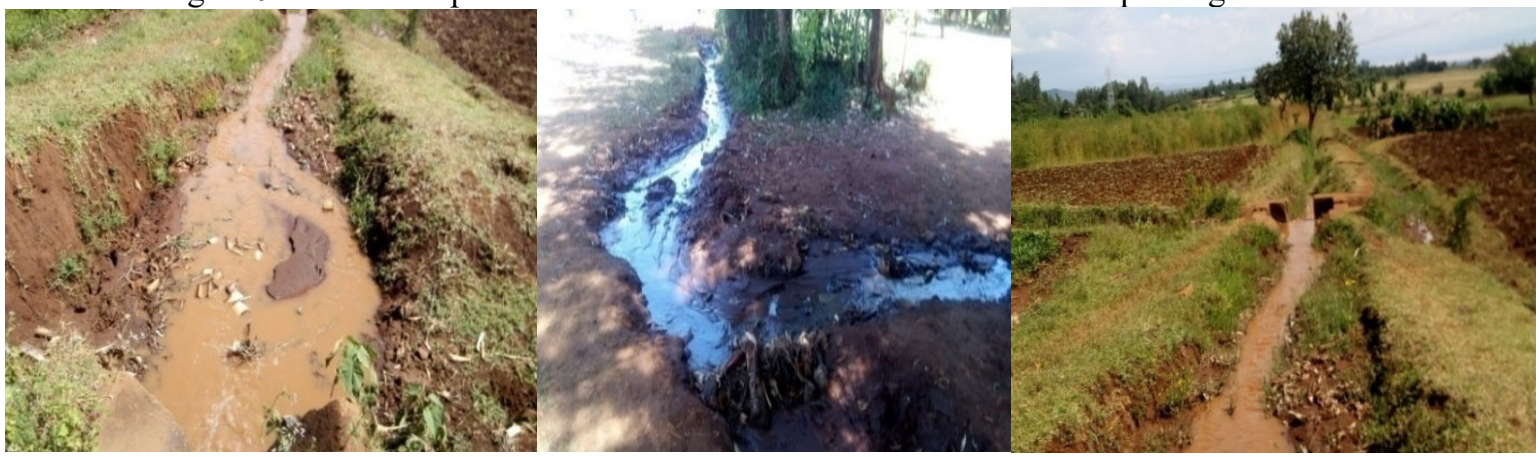

Source: Direct photos of canal problems, 2020

Management related problems: Water is not an unlimited resource and its use and distribution need to be regulated among different competing users. Appropriate water policies as well as water laws are, therefore, important for the achievement of effective utilization of water resources. Water Use Association's Bylaw is apparent in formalizing the relationship between members and in conflict resolution. However, lack of appropriate water laws and policies; absence of irrigation association bylaws; conflicts, and sense of ownerships are some of the prevailing management problems of irrigation schemes. Irrigation schemes have only a sort of bylaws which at present are not effectively serving all members. Besides, all beneficiaries of respective schemes are not actively participating in formulating bylaws. Further, although the laws specify penalties and sanctions to be imposed on offenders, punishments are not carried out on the criminals.

Mainly two types of conflicts were presently being observed: conflicts between irrigation users and other parties (i.e. upstream /downstream/ users, and other user groups) for water competition; and conflicts between irrigation water users themselves. When upstream side users use water, the volume of water for down catchment users /other parties/ reduced and water shortage occurred for their livestock and other home uses and hence conflicts occur.

Pattern of dependency on government for irrigation investment left farmers without a sense of ownership and subsequently eroded their responsibility for their operation and management as well. To this end, it was observed that almost in all irrigation schemes farmers' sense of ownership is very weak.

\section{ECONOMETRIC RESULTS OF THE STUDY}

Before estimation of parameters, it was tested for basic assumptions of the model (Heteroscedasticity and multicollinearity). Accordingly, after checking and assuring for no existence of Heteroscedasticity and multicollinearity problems, parameters of the model were estimated.

Based on the regression result, location of the household from river side, household income, age of household head, number of livestock, access to market, sex of household head, and education level of household were found to be significantly determining household decision to participate on small scale irrigation practices.

Table 6: The summarized regression results of the model using Odds ratio

\begin{tabular}{|c|c|c|c|c|c|c|}
\hline PASSI & Odds Ratio & Std. Err. & $\mathbf{Z}$ & $\mathbf{P}>\mathbf{Z}$ & \multicolumn{2}{|c|}{ [95\% Conf. Interval] } \\
\hline Locriv & $5.8225^{* * *}$ & 2.665714 & 3.85 & 0.000 & 2.37363 & 14.28287 \\
\hline Hhi & $7.3499 * * *$ & 3.984539 & 3.68 & 0.000 & 2.540026 & 21.26845 \\
\hline Tlsha & .42998 & .2811632 & -1.29 & 0.197 & .1193569 & 1.548987 \\
\hline Educ & $3.9854 * *$ & .1873003 & 1.96 & 0.050 & .1586511 & 1.001171 \\
\hline Hhsize & .38523 & .3218593 & -1.14 & 0.254 & .0749126 & 1.981049 \\
\hline Livtnubr & $4.4349 * *$ & 2.871749 & 2.30 & 0.021 & 1.246556 & 15.77846 \\
\hline Amkt & $8.5361 * *$ & 8.603278 & 2.13 & 0.033 & 1.184022 & 61.54031 \\
\hline Sex & $6.099 * *$ & 5.502129 & 2.00 & 0.045 & 1.040595 & 35.74208 \\
\hline Age & $5.91097 * * *$ & 3.249522 & 3.23 & 0.001 & 2.012405 & 17.36209 \\
\hline Crdt & .5695 & .4777825 & -0.67 & 0.502 & .1100186 & 2.948413 \\
\hline Tranig & 5.2791 & 4.63762 & 1.89 & 0.58 & .9435984 & 29.53454 \\
\hline Extenda & 1.37 & 1.17346 & 0.37 & 0.713 & .2555923 & 7.342267 \\
\hline cons & .0092 & .0002059 & -4.46 & 0.000 & $1.73 \mathrm{e}-06$ & .0057316 \\
\hline \multicolumn{7}{|c|}{$\begin{array}{l}\text { Number of obs. }=150 \\
\text { LR chi2 }(12)=141.84 \\
\text { Prob }>\text { chi2 }=0.0000 \\
\text { Pseudo } R 2=0.6825\end{array}$} \\
\hline
\end{tabular}

Source: own computation from survey data, 2019 
Location of households from river side: in this study, location of households from river side was significantly and positively determining $\mathrm{HH}$ decision to participate on SSI practices at 1 percent significance level. That is, the odd of being participated on SSI practices of HHs located at upper stream is 5.8225 times higher than that of HHs located at downstream side. This tells as there is significant difference of $\mathrm{HH}$ participation on SSI practices between those HHs who located at upstream river side and who located at downstream river side (i.e. those HHs who located at upstream river side are more likely participating on SSI practices than those who located at downstream river side. The result is consistent with the finding of Chazovachii, B. (2012) in Bikita District, Zimbabwe.

Number of livestock owned is also another important variable which was significantly and positively determining HH decision to participate on SSI practices at 5 percent significance level. That is, the odd of being participated on SSI practices of HHs who own large livestock number is 4.4349 times higher than that of HHs own smaller livestock number. This tells as there is significant difference of HH participation on SSI practices between those farmers who own large livestock number and those own small livestock number (i.e. those who own large livestock number are more likely participating on SSI practices than those own small livestock number. The result is consistent with the finding of Agerie Nega (2016) in Northern Gonder Zone, Ethiopia.

Monthly household income was also significantly and positively determining $\mathrm{HH}$ decision to participate on SSI practices at 1 percent significance level. That is, the odd of being participated on SSI of households with higher monthly income is 7.3499 times higher than that of with low monthly income. This tells as there is significant difference of HH participation on SSI practices between higher income category and lower income category (i.e. higher income HHs are more likely participating on SSI practices than the lower income category). This result is consistent with the finding of Abebaw et al. (2015) in Ethiopia.

Another important variable 'access to market' was also significantly and positively determining HH decision to participate on SSI practices at 5 percent significance level. That is, the odd of being participated on SSI practices of HHs that have better access to market is 8.5361 times higher than that of HHs with no access to market. This implies that there is significant difference between HH participation on SSI practices of those farmers who have better access to market and those who have no access to market (i.e. those HHs who have better access to market are more likely participating on SSI practices than those who have no access to it). The result is consistent with the finding of Agerie Nega (2016) in Northern Gonder Zone, Ethiopia.

Education level of $\mathrm{HH}$ head is also another important variable that was significantly and positively determining HH decision to participate on SSI practices at 5 percent significance level. That is, the odd of being participated on SSI practices of HHs whose heads attended in higher education is 3.9854 times higher than that of whose heads are illiterate. This informs that greater proportion of farmers are illiterate and primary class complete and hence there is significant difference of HH participation on SSI practices between educated farmers and illiterate farmers (i.e. educated farmers are more likely participating on SSI practices than illiterate farmers).The result is consistent with the finding of Agerie Nega (2016) in Northern Gonder Zone, Ethiopia.

Age of $\mathrm{HH}$ head (Age): this variable was also significantly and positively determining $\mathrm{HH}$ decision to participate on SSI practices at 1 percent significance level. That is, the odd of being participated of adult-aged $\mathrm{HH}$ heads on SSI practices is 5.91097 times higher than that of old-aged HH heads. This shows that adult-aged farmers are more likely participating on SSI practices than old-aged and younger farmers. The result is consistent with the finding of Chazovachii, B. (2012) in Bikita District, Zimbabwe.

Sex of HH head was also significantly and positively determining HH decision to participate on SSI practices at 5 percent significance level. That is, the odd of being participated on SSI practices of male headed HHs is 6.099 times higher than that of female headed household. This indicates that male headed households are more likely participating on SSI practice than female headed households. This result is consistent with the finding of Dagninet Asrat, (2019) in Ethiopia.

\section{CONCLUSION AND POLICY IMPLICATIONS}

The objective of this study was analyzing the determining factors of HH decision to participate on SSI practices in three selected districts of Wolaita Zone, Ethiopia. To this end, according to descriptive result, $71.33 \%$ of households are non-irrigation users and they have no access to participate on SSI practices. It is also indicated that irrigation scheme's maintenance; water user association; implementation of law and management systems are week. Two irrigation schemes (namely: Abela Maraka-Lasho and Abaya Bissare) are poorly managed and collapsed canal banks, unstable embankments due to unsuitable soil, leaking lining in elevated embankments, crabs and other animals dig holes in the embankment and cattle climbing in and out of the canal are the particular problems of irrigation schemes. Such problems also led to canal deterioration, reduced flow and frequent disturbance of irrigation supply. In addition, lack of appropriate water laws and policies, absence of irrigation association bylaws, conflicts, and sense of ownership are also management related problems on irrigation schemes in the study area. Binary logistic regression result revealed that location of $\mathrm{HH}$ from river side, household income, age of $\mathrm{HH}$ head, number of livestock, access to market, sex of household head, and education level of HH head 
were found to be significantly and positively determining household decision to participate on small scale irrigation practices in the study area.

Based on findings, the authors forwarded some of important recommendations to the government, nongovernmental organizations and other stakeholders:- (1) households who located far from river side should develop different water conservation structures such as community pond, household pond, and other types of structures to hold water on their farm land; (2) focuses should be given on construction of new main irrigation canals for farmers who located at the downstream side of the river to minimize water lose; (3) institutional support and continuous monitoring and evaluation of irrigation schemes are also necessary to solve the existing management related problems on irrigation scheme and water user association; (4) expanding the capacity of small-scale irrigation agriculture and creating additional access through integrated water investment is also important to increase agricultural production and productivity. In this regard, give emphasis on provision of credit for farmers that improve their financial capital to purchase improved seed, fertilizer; chemical and other necessary equipment's; (5) from the main sources, irrigation water is distributed for the farmers at a night time and it is not preferable for women especially who have small family size. Therefore, promoting female farmers by supplying credit services to purchase agricultural inputs and use labor forces for irrigating crops at night time and other necessary supports should be given by government and non-governmental organizations; (6) emphasis should be given on provision of regular awareness creation training to improve farmers' awareness and skill about irrigation technologies and increases their access to irrigation water.

\section{REFERENCE}

Abebaw A., Mesfin T, Ermias M. 2015. Determinants small scale irrigation utilization by small holder farmers in rift valley basin Vol.5, No.21

Agerie Nega, (2016). Determinants of Smallholder Rural Farm Households' Participation in Small Scale Irrigation and Its Effect on Income in North Gondar Zone of Amhara region, Ethiopia;

Chazovachii, B. 2012. The impact of small scale irrigation schemes on rural livelihoods: The case of Panganai irrigation scheme Bikita District, Zimbabwe. J. Sust. Dev. Afr. 14(4): 217-231.

Chiza C.K. 2005. The role of irrigation in agriculture, food security and Poverty reduction. A paper presented to the 3rd Annual Engineer's Day, Learned Discourse, Dares Salaam, Tanzania.

Dagninet Asrat, (2019). The determinants of irrigation participation and its impact on the pastoralist and agropastoralists income in Ethiopia: A review study

Haile T., (2008). Impact of irrigation development on poverty reduction: in Northern Ethiopia: M.Sc. Thesis. National University of Ireland, Cork, Ireland;

Hosmer DW, Lemeshow S. (2008). Applied Survival Analysis, 2nd Edition, New York;

John W. Creswell, (2014). Research Design, Qualitative, Quantitative and Mixed Methods Approaches; Fourth Edition; University of Nebraska-Lincoln

Tesfaw M. (2018). Land tenure and plot size determination issues in Small-Scale irrigation development: in Tigray, northern Ethiopia. pp.129-139: Proceedings of the Workshop on Current Issues on Land Tenure in Ethiopia,

WZIDO, (2018). Wolaita Zone Irrigation Development Office; Unpublished secondary data on irrigation development of Wolaita zone;

Yemane T. 1967. Statistics, an Introductory Analysis:, 2nd Ed., New York, and Row; 